\title{
Cash Transfer Programme in Malaysia - A Conceptual Analysis
}

Mohd Ahadan Md Nooh, Geetha Subramaniam, and Mohd Hafiz Hanafiah

To Link this Article: http://dx.doi.org/10.6007/IJARBSS/v11-i2/7992

DOI:10.6007/IJARBSS/v11-i2/7992

Received: 06 January 2021, Revised: 01 February 2021, Accepted: 17 February 2021

Published Online: 28 February 2021

In-Text Citation: (Nooh et al., 2021)

To Cite this Article: Nooh, M. A. M., Subramaniam, G., \& Hanafiah, M. H. (2021). Cash Transfer Programme in Malaysia - A Conceptual Analysis. International Journal of Academic Research in Business and Social Sciences, 11(2), 494-507.

Copyright: (c) 2021 The Author(s)

Published by Human Resource Management Academic Research Society (www.hrmars.com)

This article is published under the Creative Commons Attribution (CC BY 4.0) license. Anyone may reproduce, distribute, translate and create derivative works of this article (for both commercial and non-commercial purposes), subject to full attribution to the original publication and authors. The full terms of this license may be seen

at: http://creativecommons.org/licences/by/4.0/legalcode

Vol. 11, No. 2, 2021, Pg. 494 - 507

http://hrmars.com/index.php/pages/detail/IJARBSS

JOURNAL HOMEPAGE

Full Terms \& Conditions of access and use can be found at http://hrmars.com/index.php/pages/detail/publication-ethics 


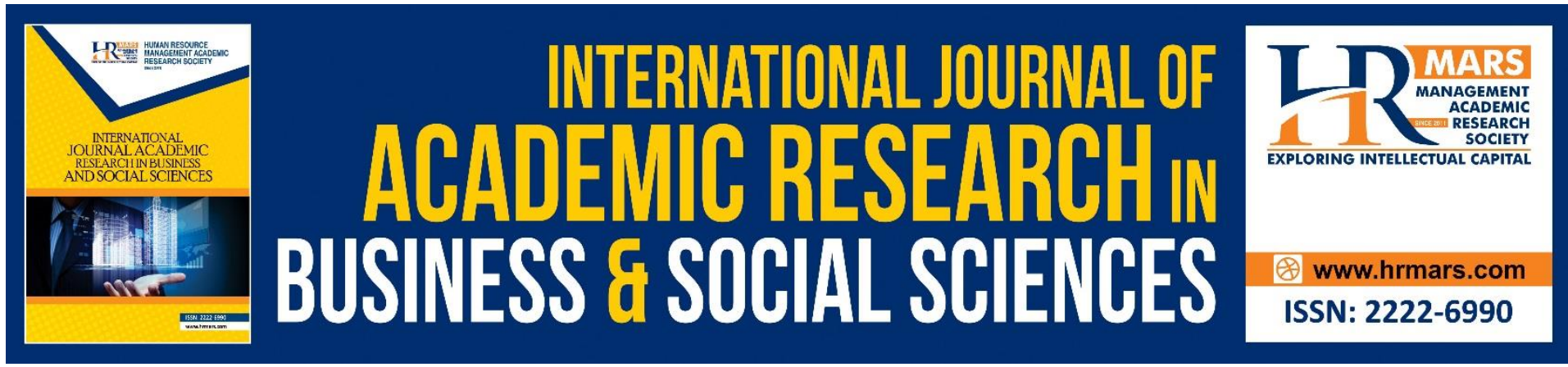

\title{
Cash Transfer Programme in Malaysia - A Conceptual Analysis
}

\author{
Mohd Ahadan Md Nooh ${ }^{1,2}$, Geetha Subramaniam², and Mohd \\ Hafiz Hanafiah ${ }^{3}$ \\ ${ }^{1}$ Public Service Department, Malaysia, ${ }^{2}$ Faculty of Business and Management, Universiti \\ Teknologi MARA, Selangor, ${ }^{3}$ Faculty of Hotel and Tourism Management, Universiti Teknologi \\ MARA Puncak Alam Campus \\ Email: gee395@uitm.edu.my
}

\section{Abstract}

Poverty eradication remains an important agenda today and is one of the key indicators in the Millennium Development Goals (MDGs) and Sustainable Development Goals (SDGs). One of the initiatives to address poverty among the poor and vulnerable groups implemented in many countries is the cash transfer programme (CTP). In 2012, the Bantuan Rakyat 1 Malaysia (BR1M) scheme was introduced as one of the CTPs in Malaysia, which was recently rebranded as Bantuan Sara Hidup (BSH). However, in spite of the merits of CTP, one of the main critiques is that it does not provide evidence of meaningful impact on the community and does not reach its intended target. Hence, this conceptual paper first examines best practices of CTP in other countries and the recipients' perception on CTP. This paper further explores some issues with regards to CTP in its aim to address the cost of living and quality of life issues. This conceptual study would form a theoretical framework for further empirical work to be done so that it can be used by policy makers and stakeholders to design and improve CTPs to achieve better outcomes.

Keywords: Poverty Eradication, Cash Transfer Programme, BR1M/BSH, Cost of Living, Quality of life, Well-being, SDG.

\section{Introduction}

Poverty eradication still remains an important agenda today and is one of the key indicators in the Millennium Development Goals (MDGs) and United Nation's Sustainable Development Goals (SDGs). Recently, the SDGs 2030 Agenda set out a 15-year plan to achieve the goals, whereby eradicating poverty remains number one among the SDGs. One way of eradicating poverty is through social protection strategy which if carefully designed may address poverty and exclusion. Cash transfer programme (CTP) is one of the initiatives employed by many countries as a social protection strategy to address poverty among the poor and vulnerable groups. The main aim is to protect the vulnerable groups from the pressure of high cost of living and at the same time, allow them to have more choices in life.

According to UNICEF (2019), CTP allows families to access healthcare, good nutrition, and quality education. CTPs are fundamental social protection strategies of developing 
nations (Slater, 2011) and guarantees a decent level of quality of life (Checcini \& Martinez, 2012). A study by Llyod-Sherlock (2004) revealed that CTP could improve quality of life and the ability to deal with opportunities and risks related to dynamics of change.

In the Malaysian context, significant strategies which have been taken to tackle the rising cost of living and disproportion of income (OECD, 2019b). Some of the strategies include direct cash transfers to households with a monthly income of MYR 4000 and below, affordable housing programme for the low-income households, as well as the provision of subsidies and price control for selected essential goods (OECD, 2019b).

Despite these efforts, the low-income group remain particularly vulnerable to economic shocks and increase in the cost of living and end up facing mounting financial obligations (World Bank, 2020). The Malaysian daily (The Star, 2018) recently reported that low-income households remain vulnerable to the shocks and emergencies due to low savings, as nearly 95 percent of their incomes are spent on everyday expenditure, particularly on necessities. Furthermore, they have low wealth and non-financial asset ownership and are highly dependent on government assistance (UNDP, 2016).

In Malaysia, cash assistance has been provided by the government to cushion the impact of the rising cost of living (Kamaruddin et al., 2013) since its introduction in 2012. However, the Malaysian-based CTP programme has received many criticisms from various parties. Even after the rebranding from Bantuan Rakyat 1Malaysia (BR1M) to Bantuan Sara Hidup (BSH) people perceive it as an attempt to woo votes from vulnerable groups (Chinnasamy \& Azmi, 2018). Some even claim that such expenditure will endanger the nation in the future (New Straits Times, 2018). For some, BR1M has been a respite for the challenges they face in life. This is especially true after the goods and services tax (GST) was implemented and petrol subsidies were removed in 2018. But few parties argue that cash assistance is not a long-term solution to underlying social inequality problems. One reason why many object to the programme is because it does not hold a long term value as it is claimed that it does not address the root cause of poverty (The Star, 2018). Nonetheless, the merits of BR1M should be assessed to understand the direct and spill-over impact better.

This conceptual paper first gives a theoretical overview of CTPS and deliberates on best practices of CTP globally and in the Malaysian context. Two underpinning theories which form the framework of the paper are briefly discussed. It then further examines three major issues CTPs in Malaysia are linked to. The paper finally ends with an urgent need for a future study on an empirical work to be conducted on to what extent CTP can address cost of living and quality of life issues in Malaysia.

\section{Hence the Objectives of this paper are}

- To review some best practices of CTP implemented in other countries.

- To discuss recipients' perception on CTP.

- To explore how CTP may be an initiative to address the cost of living issue

- To explore whether CTP may be a scial protection strategy to address quality of life issue.

\section{Overview of Cash Transfer Programme (CTP)}

Cash transfer programme (CTP) to the poor and vulnerable groups has become popular among many governments. Figure 1 is an overview of two types of CTP which are targeted and universal (untargeted): 


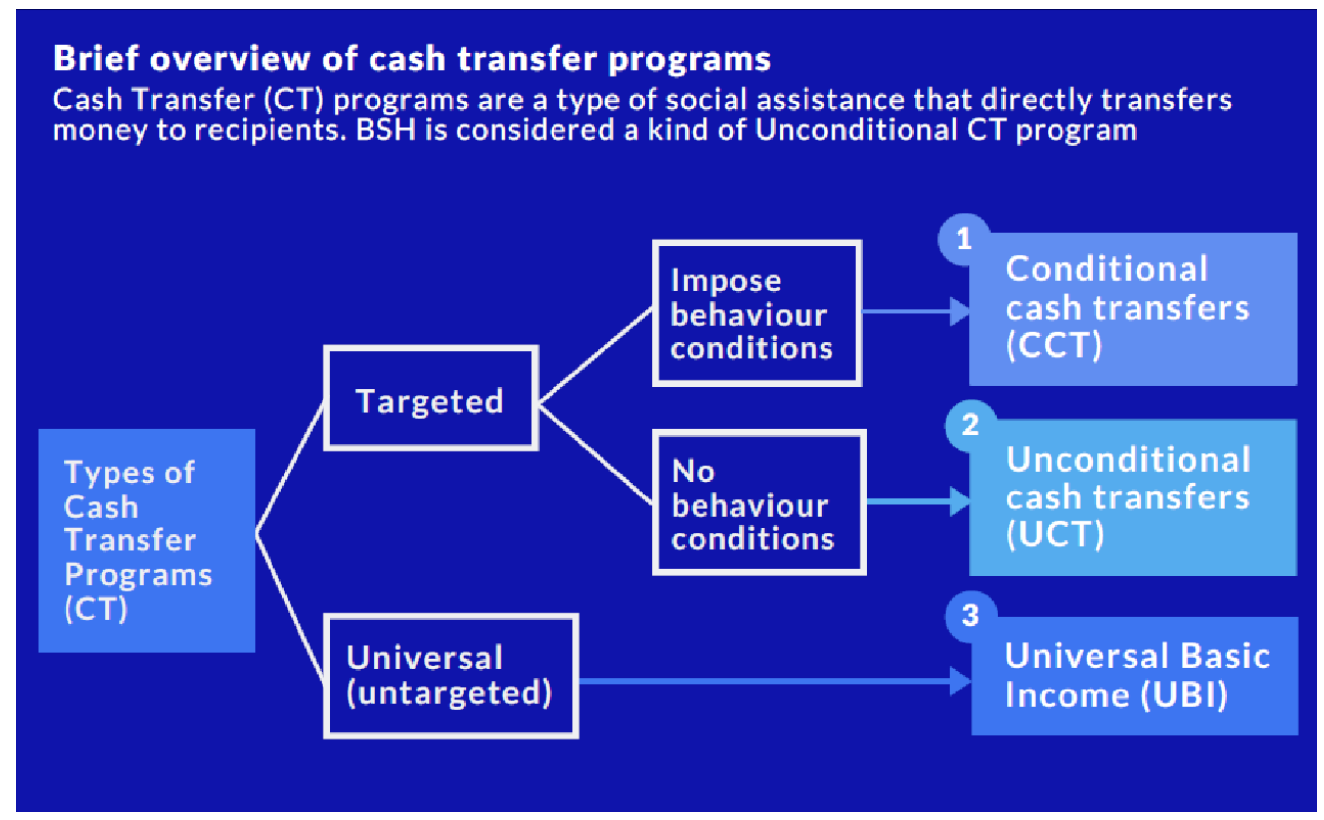

Figure 1: Brief overview of cash transfer programmes

Source: Bastagli (2010)

There are two types of cash transfer programmes (CTPs), namely targeted and universal. Targeted CTPs either impose behaviour conditions or non-behavioural conditions. Meanwhile, universal cash transfer imposes no conditions.

Conditional cash transfer (CCT) provides cash to eligible recipients with certain conditions (Lagarde et al., 2009). This requirement may include incentivising attendance for health education, measurements of height and weight, immunisations and nutritional supplementation. CCTs appear to be an effective way to increase the uptake of preventive services and encourage preventive behaviour (Lagarde et al., 2009). Other than reducing poverty, CCTs also aim to eradicate poverty for future generations through human capital development (Behrman et al., 2017). CCTs in Asia assist households, while the conditions imposed help to shape a better future. The transfers are useful, but it is the health and education benefits that are lasting and empowering (ADB, 2013).

On the other hand, unconditional cash transfers (UCTs) have become a popular tool to combat poverty in developing nations (Baird et al., 2013; Blattman et al., 2014). According to Haushofer and Shapiro (2016), UCTs relate to flexibility. In addition, UCTs are lower in cost, as there are zero requirements for monitoring. However, UCTs have its disadvantages: they may be used unwisely which defeat the purpose; disincentive work (Cesarini et al., 2015); or lead to disagreements within the parties concerned (Bobonis et al., 2013; Hidrobo et al., 2016).

\section{Cash Transfer Programme - International Scenario}

Mills (2019) found that poor, vulnerable children and their families have benefitted from social protection. Currently, many Asian countries have adopted the strategy of giving out cash to the poor and vulnerable groups to help them overcome the pressure of high cost of living. The standard payments of cash transfers are essential in creating economic empowerment while alleviating poverty and improving food security (UNICEF, 2019). 


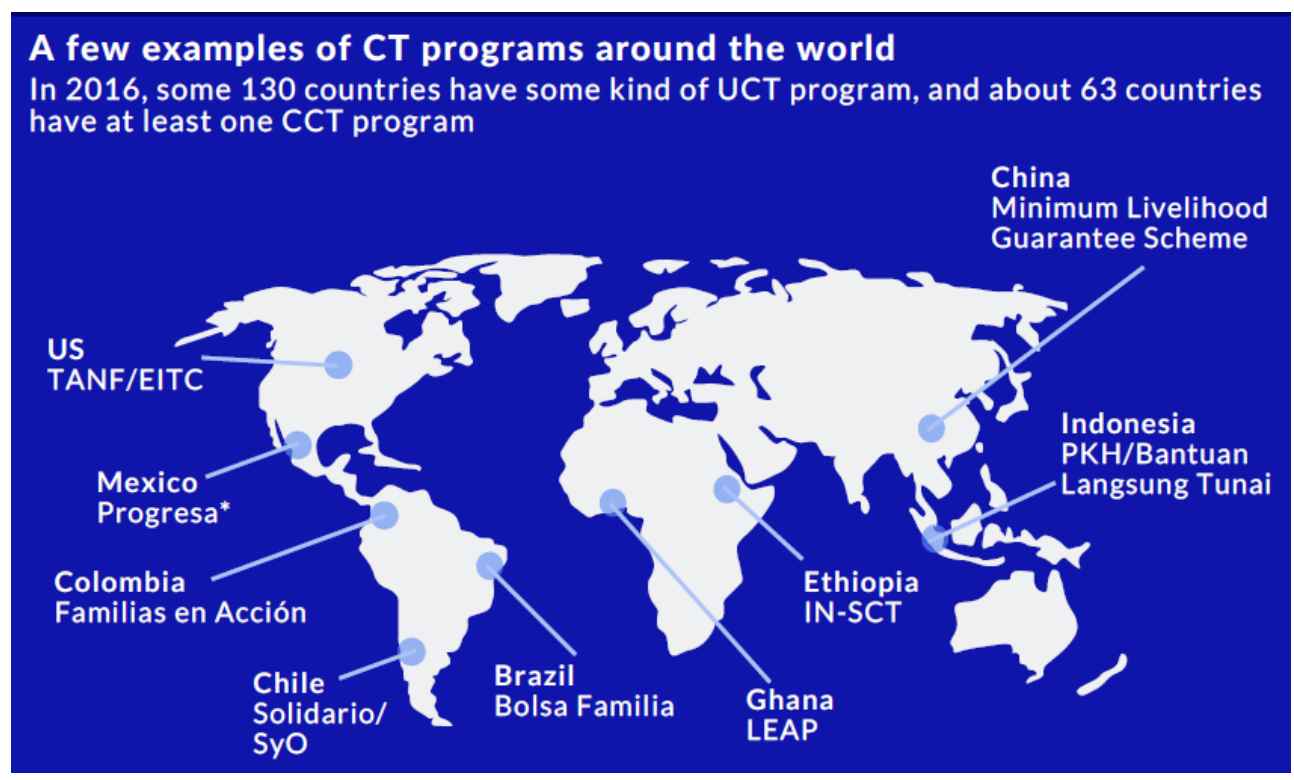

Figure 2: Cash Transfer Programmes around the world.

Source: Bastagli (2010)

Figure 2 shows a few examples of CTPs around the world. In 2016 itself, there were about 130 countries globally which implemented unconditional CTPs while 63 countries implemented conditional CTPs. In Asia, a simple act of directly giving cash to the people who need it the most remains a powerful tool and CTPs have demonstrated a significant and positive impact on the income-generating activities of recipients who contribute to improving livelihoods (UNICEF, 2019). Cash transfers, as they are popularly known in most parts of the world, have for decades been provided to those in need, particularly in the aftermath of disasters. Cash transfers or cash handouts form an important and growing part of the social protection programme in many developing countries (Slater, 2011).

In the last 15 years, conditionality has been attached to these transfers, making them a much more powerful form of social assistance (ADB, 2013) ADB (2020) highlights the percentage of people living in extreme poverty as measured by surviving on less than USD1.90 per day (2011 purchasing power parity), fell significantly in the early part of the new millennium from $34 \%$ in 2002 to $7 \%$ in 2015. In absolute terms, this represents a decline from 1.11 billion people in extreme poverty to 264 million people where the majority of the decline came from East Asia (409 million to 10 million) and South Asia (505 million to 202 million) (ADB, 2020).

\section{Cash Transfer Programme in Malaysia}

In 2012, the Bantuan Rakyat 1Malaysia (BR1M) scheme was introduced as a CTP in Malaysia. A study by World Bank (2018) found that BR1M has had a significant impact on the wellbeing of the people by providing relief to the recipients and enabling them to acquire the basic goods and services. The scheme was rebranded as Bantuan Sara Hidup (BSH) in 2018 and administered by the Malaysian Inland Revenue Board (LHDN). BSH serves as direct and targeted assistance to the low income groups known as the B40 (Bottom 40\%) to relieve the strain arising from subsidy rationalisation. The B40 group refers to households earning below a median income of MYR3,166 each month (DOSM, 2019). 


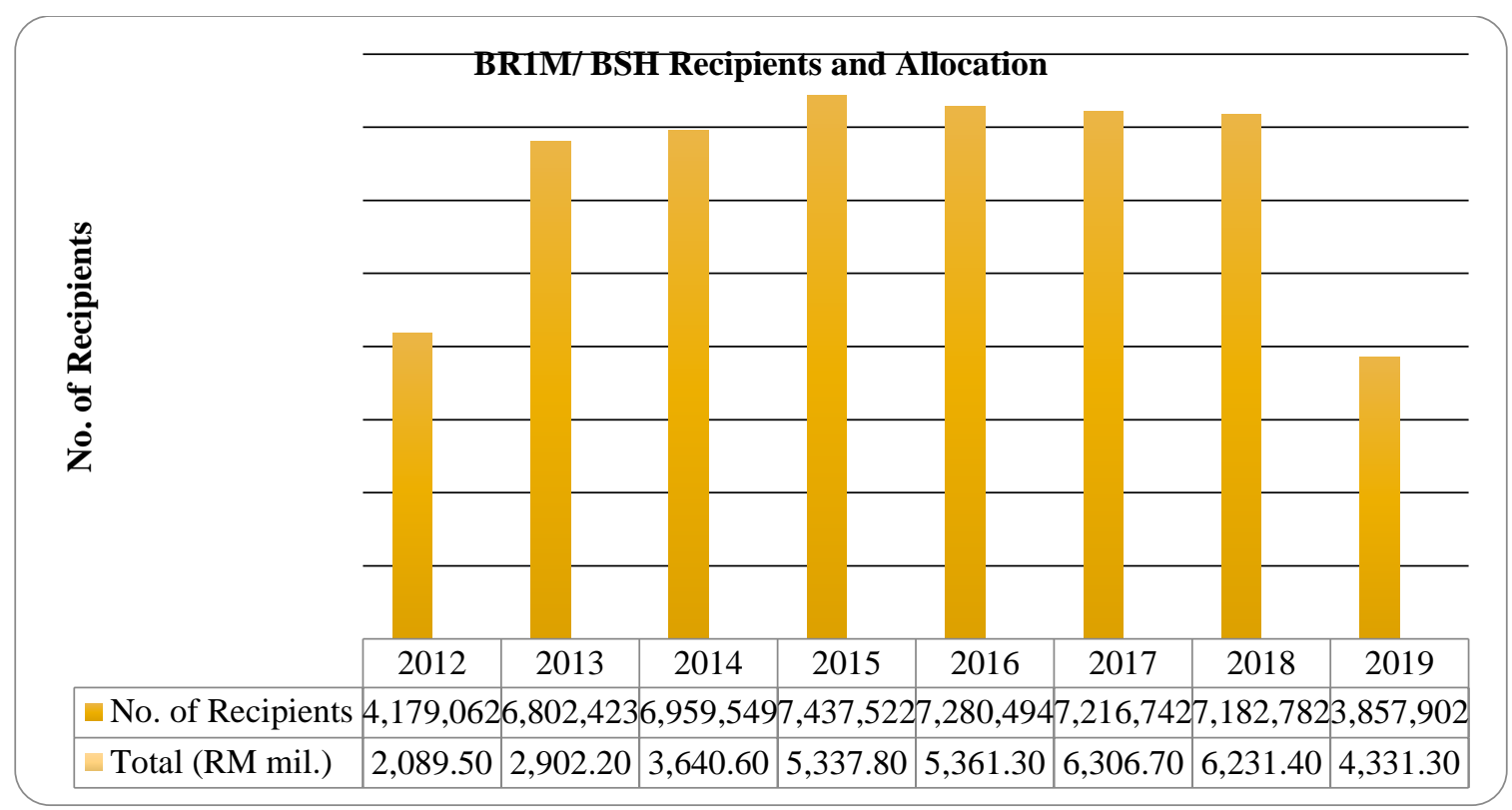

Figure 3: BR1M/ BSH Recipients and Allocation

Source: BSH Secretariat, MOF Malaysia (2020)

Figure 3 shows the BR1M/BSH recipients and allocation from 2012 until 2019. Since 2012, more than MYR25 billion was spent on BR1M handouts. (BSH Secretariat, 2020). During the first launch in 2012, a total of MYR2.089.5 billion was disbursed to 4,179,062 households under a single category which is 'households with a monthly income of below MYR3000'. However, from 2013, the number of recipients and allocations increased as the government included a second category called 'unmarried individuals with an income of below MYR2000 per month'. With the increasing awareness, more and more households below the MYR3000 category registered under BR1M. The upward trend and categories continued until 2015. However, in 2016, the number of recipients and allocations decreased despite an increase in total amount allocated. The downward trend continued until 2018 when BR1M was revised and renamed as Bantuan Sara Hidup (BSH) after the change in government. Since 2019, the numbers continued a downward trajectory as the government mulls to phase out BSH due to sustainability issues.

\section{The Issue}

\section{CTP and its aim of addressing poverty}

CTPs are increasingly used as a social protection mechanism to tackle poverty and the issue of wellbeing for vulnerable groups (Floate et al., 2019). Since its introduction in 2012, the Ministry of Finance reports that more than MYR36 billion has been spent on BR1M and BSH (BSH Secretariat, 2020). However, since its introduction, there are a number of criticisms on the implementation of the CTP. According to the World Bank, the rate of BR1M/BSH handouts is still low, and as a result, it has not given a meaningful impact in reducing poverty and inequality (New Straits Times, 2019). The impact can only take place if the amount of BSH is increased, targeting is improved, and household income follows the same trend (New Straits Times, 2019). On the other hand, many argue that the amount spent by the Malaysian government for this programme each year is large and this amount may not be sustainable in the long run and is reducing every year (New Straits Times, 2018). 


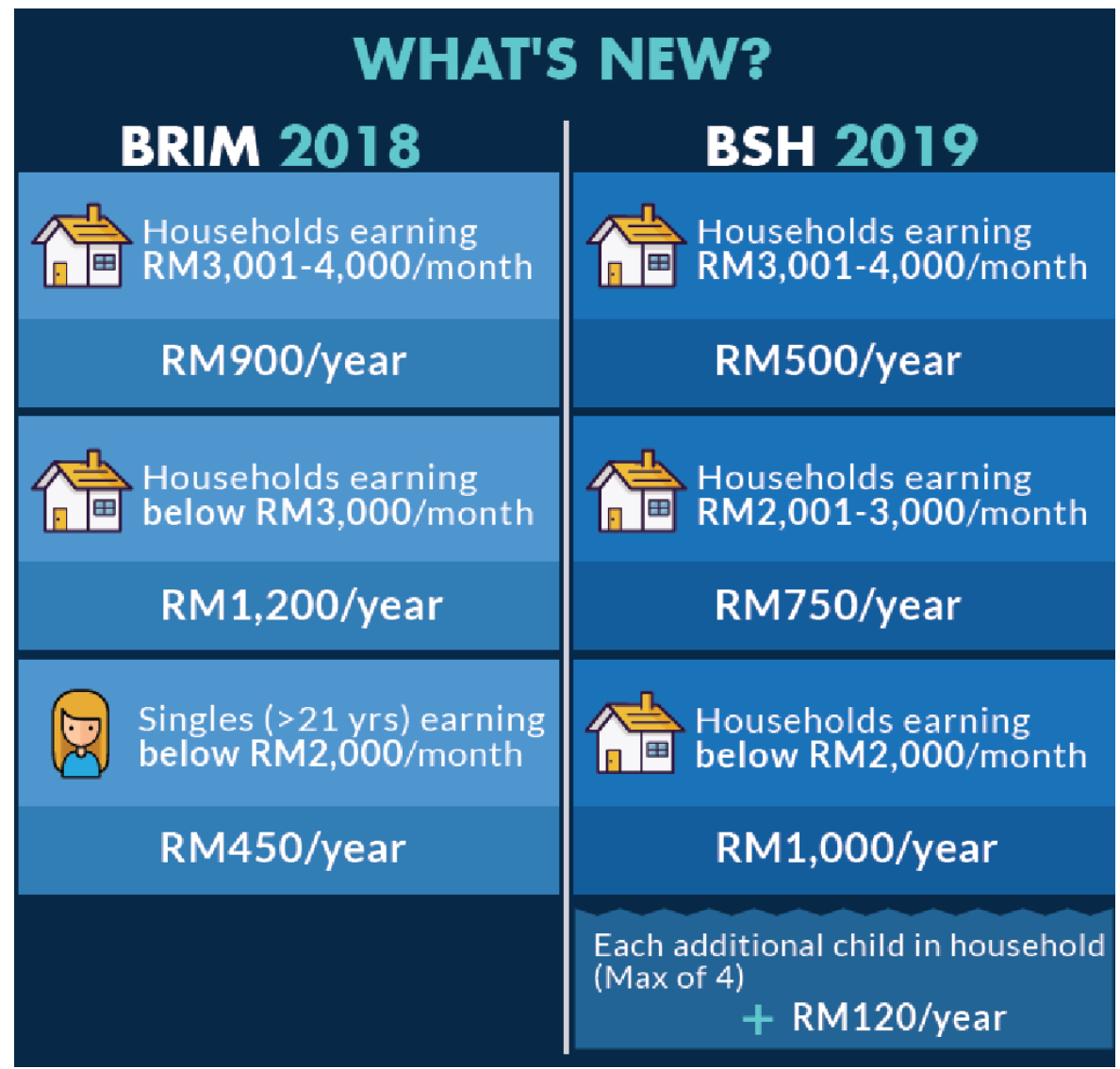

Figure 4: BR1M vs. BSH

Source: Institute of Strategic \& International Studies (ISIS) Malaysia (2019)

Figure 4 illustrates the reduction of pay-out between BR1M 2018 and BSH 2019. Despite the reduction in the quantum of the handouts, the government introduced a criterion where each household with a child will receive an addition of MYR120, with a maximum of 4 children per household.

On the other hand, there are claims that BR1M remains out of reach for many within the target group. Indigenous communities and those in rural areas still find it challenging to access the scheme via the Internet to complete the registration forms, which is made worse with illiteracy among eligible recipients and the absence of a formal bank account (The Edge, 2016). Furthermore, the gaps in ensuring access, the broad eligibility standards and defective procedures could mean that much of the money spent is missing the target community. In the meantime, supporters of BR1M/BSH programme agree that it is beneficial for the people, but that it has not reached its intended target. It was reported that even individuals carrying the title "Datuk" were recipients of BR1M (The Sun, 2019).

There has been limited discussion on how BR1M/BSH money is spent by the recipients to help address the high cost of living. It is claimed that the BR1M/BSH programme has not helped the beneficiaries as much as it should be as it is a one-off payment whereas bills and necessities need to be paid every month (New Straits Times, 2019).

Furthermore, there is also very limited study on the perception of urban poor BR1M/BSH recipients on the CTP as a social protection strategy in Malaysia. This is likely because it is still too soon to investigate such outcomes as even the earliest programmes only began in 2012. However, there are reports that the Malaysian government intends to gradually reduce BR1M or BSH payments before scrapping the programme entirely in the near 
future (New Straits Times, 2019). Since many have argued that the CTP typically contributes in contexts with a short-term outcome, the magnitude of any such long-term impact is an empirical question and should be explored further.

\section{Theoretical Considerations of CTP}

Two theoretical explanations can be used to explain how CTP can be linked to poverty eradication and increased living standards and improved quality of life.

\section{Structural Theory of Poverty}

The Structural Theory of Poverty, developed during the 19th century by Marx (1932), assumes that poverty is a result of the social structure and economic system which creates inequality among groups. He argues that capitalism creates a condition that promotes poverty. In some studies, it is argued that the economic system is structured in a way that the vulnerable groups are left behind regardless of their high capabilities. The structural barriers restrict the poor from employment (Bradshaw, 2007). Hence from the structural poverty perspective, if the problem is the system rather than the poor themselves, community intervention like equalising income distribution through the provision of cash transfer to the poor household will help to alleviate poverty. This is because cash transfers will enable them to access basic necessities such as food, education, and health.

\section{Human Capital Investment Theory}

The Human Capital Investment theory developed by Becker (2010), posits that human capital investment involves investing in human capital through education, expenditure and medical care as well as training so as to improve skills, talents, abilities and competencies which in turn would increase productivity and performance in different activities. Marimuthu et al. (2009) found that human capital investment involves an initial cost where the individual hopes to gain a return in the future. For example, by investing money in education and healthcare services, the returns expected are an increase in the labour force and level of productivity. Thus, cash transfers may be an approach under this theory which may lead to the improvement of living standards which in return increases productivity.

\section{Research Proposition}

Social protection and cash transfer play a key role in promoting equity and social cohesion (World Bank, 2019), which is important especially for the vulnerable groups. Yet, this measure has large financial requirements and therefore may impact the financial position of the government as it may not be sustainable in the future (OECD, 2019b).

\section{Recipients' Perception of Cash Transfer Programme (CTP)}

Many studies have been done to show CTP recipients' perception and how the cash handouts are used. Shapiro (2019) mentioned that cash transfers increase feelings of autonomy and respect compared to non-cash interventions. Meanwhile, Handa et al. (2018) argue that CTP has potential in improving well-being and strengthening livelihood among the poor. For instance, cash transfers have increased the spending power of the poor where the money is used for food and education (Yildirim et al., 2014). Cash transfers also have improved the health conditions of the vulnerable group because it increases vaccination participation among kids (Skovdal et al., 2013). Besides, improvement in community social participation (Selvester et al., 2012), enhanced social unity and more community interactivity 
is evident with cash transfers (Skovdal et al., 2013). The wellbeing of children in terms of increased level of confidence and self-esteem was highlighted by some studies too (Yildirim et al., 2014).

In a study in Zimbabwe, Skovdal et al., (2013) found that expected income and support reduces pressure and anxiety and improves the emotional health of parents and guardians because they have less worry about where to get the money from. However, in some cases, there are gaps found between the possible and actual use of the transfer. For instance, in Indonesia and Zimbabwe, men use the transfer for personal needs rather than for the family (Skovdal et al., 2013) and sometimes men spend the money unnecessarily (Hossain et al., 2012). Nevertheless, in some areas, the recipients say that the transfer is insufficient to meet all their requirements; it only covers some immediate needs like foodstuff (Benasius, 2017).

\section{Targeting in Cash Transfer Programme (CTP)}

Targeting is a major challenge in social protection. While Filmer et al. (2018) argues that targeted CTP significantly raises the local prices of foods, on the other hand, Handa et al. (2018) found that targeted CTP has far-reaching effects on food security, consumption as well as on a range of productive outcomes. Errors in targeting have been discussed in previous research work (Brown et al., 2016). Error in targeting happens due to the absence of an integrated system to validate the authenticity and genuine application from the claimants. Errors also happen because of the ineffectiveness of the management and administration of the organisation in the aspect of the system, procedures, manpower and others (Grosh et al., 2008).

Hence proper targeting is vital for efficiency (Slater \& Farrington, 2010) and can be highly challenging, especially in countries where poverty headcounts are high and the differences between the lower deciles in the poverty and income profile are negligible (Ellis, 2008). In addition, the design and implementation of the program in many countries are mostly done by the central government. Most of the time, programmes try to use a wide range of targeting methods to ensure that benefits effectively reach the poorest household.

\section{Impact of CTP on Cost of Living}

Studies have shown that CTP has an impact on cost of living indirectly. For example, CTP empowers poor, rural households facing negative shocks to employ coping strategies, which enables them to increase their food consumption and overall food security substantially (Lawlor et al., 2019). It also helps in meeting basic consumption needs, (Daidone et al., 2019) and improve primary school participation as it reduces the need to enter labour market (Maluccio \& Flores, 2004; Vincent \& Cull, 2008). Moreover, the programme has been particularly effective at enabling poor households to pay for school fees in time and avoid being sent home and buy other related schooling materials such as school uniforms and stationeries (Arnold et al., 2011; Evans \& Popova., 2017). The transfers even make children look neat as uniforms and shoes can be replaced (Skovdal et al., 2013). Another important impact of CTP is improved nutrition among students which has helped them to learn better (Arnold et al., 2011)

CTP enables more expenditure on health services so as to reduce the severity of diseases facing many poor households (Bailey \& Hedlund, 2012). The money provided has proven to help households purchase different foods such as vegetables, meats, dairy and fruits (Amarante et al., 2011; Bailey \& Hedlund, 2012), increasing food security to poor 
households as it has prevented skipping meals (Bailey \& Hedlund, 2012). CTP also has a great impact on improving child growth and maternal growth (Amarante et al., 2011).

Studies have also found that CTP promotes self-esteem, status improvement and enables the poor to participate in the society (Vincent \& Cull, 2009; FAO, 2015). In another study, Arnold et al. (2011) suggest that CTP can support young girls' education and enhance women empowerment due to the tendency of putting CTP directly to women.

\section{Impact of CTP on Quality of Life}

In Malaysia, the quality of life of individuals can be viewed in many aspects including personal development, healthy living, accessibility and freedom to acquire knowledge, and enjoy living standards that exceed the basic and psychological needs of individuals to achieve a level of social welfare in line with the objective of the country according to the Economic Planning Unit (EPU). This definition is in line with Burnel and Galster (1992) who foresaw quality of life as the welfare of a person to undergo a process of life which includes aspects of nutrition, education, health, housing, and aesthetics.

Hence, the Malaysian Quality of Life Index (MQLI) was developed in 1999 and was enhanced to become the Indeks Kesejahteraan Rakyat Malaysia (IKRM). Variables measured in IKRM include communication, culture, education, environment, family, governance, health, housing, income and distribution, vacation, public safety, social inclusion, transport, and work environment. There are two more quality of life indicators in Malaysia which are The Malaysian Family Wellbeing Index by LPPKN and The Malaysian Urban Rural National Indicators Network on Sustainable Development (MURNInets) by PLANMalaysia.

Social protection improves the quality of life generally. Cheng (2019) mentioned that cash transfers reduce monetary poverty and increases food diversity and well-being. Meanwhile, de Souza et al. (2018) found that CTP leads to improvement in quality of life. Social protection, through social assistance, ensures an income sufficient to maintain a minimum quality of life for people development (Checcini \& Martinez, 2012). A study by Llyod-Sherlock (2004) revealed that social protection, both formal and informal, can play a key role in mediating the relationships between quality of life and the capacity to manage opportunities and risks associated with a rapid and complex change. More recent evidence (Checcini \& Martinez, 2012) suggests that functions of social protection are to guarantee a sufficient income to sustain a decent quality of life. Social protection includes all policies and programmes intended to improve people's quality of life through increased productivity and independently generated incomes. In their review of the Puente programme, Chile, Nun and Trucco (2008) conclude that social protection improves recipients' quality of life by meeting minimum social standards.

\section{Conclusion}

This conceptual review on CTPs in Malaysia has led to some interesting conclusions.

Firstly, CTP is a social protection strategy implemented in Malaysia since 2012 with an aim to address the cost of living issues and quality of life of the vulnerable poor. Secondly, some best practices of CTP implemented in other countries are reviewed in this paper. Thirdly, three main issues with regards to CTP in terms of recipient targeting, addressing the cost of living and quality of life are discussed. Fourthly, the many benefits of CTP and its positive impact on the recipient's quality of life are elaborated based on past studies. 
It can be seen that CTP definitely is a social protection strategy which can help address the cost of living and the quality of life of the recipients if it reaches the targeted recipient. Hence, it is pertinent that the targeted recipients receive the CTPs for this initiative to work.

Therefore, this conceptual study paves the way for an empirical study to be done to examine to what extent the CTP helps alleviate the poverty situation by helping address the cost of living issue of the vulnerable poor.

Besides, this conceptual study would form a theoretical framework for further empirical work which can be used by policy makers in designing better strategies to reach the targeted recipients. As the government is serious on SDG 1 and has many policies in place to alleviate poverty, the proposed empirical study should also explore recipients' perceptions on the effectiveness of CTP towards improving their quality of life.

This conceptual study provides the way forward for future research on cash transfer programme as there are limited studies on this issue in Malaysia. The main conclusions discussed above can add to the body of knowledge on Malaysian social protection policies and strategies. The proposed framework can be used to formulate an empirical quantitative or qualitative study to look deeper on the demand side, rather than the supply side of the social protection strategies in Malaysia.

\section{Acknowledgement}

We would like to express our appreciation to the Faculty of Business and Management, Universiti Teknologi MARA, Selangor for the funding of this study.

\section{References}

Amarante, V., Manacorda, M., Miguel, E., \& Vigorito, A. (2011). Do cash transfers improve birth outcomes? Evidence from matched vital statistics, social security and program data (No. w17690). National Bureau of Economic Research.

Arnold, C., Conway, T., \& Greenslade, M. (2011). Cash transfers literature review. London: Department for International Development.

Asian Development Bank. (2013). Conditional cash transfers (ccts) in Asia to reduce poverty [online]. Manila : Asian Development Bank

Asian Development Bank. (2020). Poverty and social statistics: Asia and the Pacific [online]. Manila: Asian Development Bank

Bailey, S., \& Hedlund, K. (2013). The impact of cash transfers on food consumption in humanitarian settings: a review of evidence. Canadian Foodgrains Bank.

Baird, S., De Hoop, J., \& Özler, B. (2013). Income shocks and adolescent mental health. Journal of Human Resources, 48(2), 370-403.

Bastagli, F. (2010) Poverty, inequality and public cash transfers: lessons from Latin America. Background Paper for the European Report on Development (ERD) 2010 on Social Protection for Inclusive Development, European University Institute, Florence

Becker, Gary. (2010). Human Capital: A Theoretical and Empirical Analysis, with Special Reference to Education.

Behrman, J. R., Schott, W., Mani, S., Crookston, B. T., Dearden, K., Duc, L. T., \& Stein, A. D. (2017). Intergenerational transmission of poverty and inequality: parental resources and schooling attainment and children's human capital in Ethiopia, India, Peru, and Vietnam. Economic development and cultural change, 65(4), 657-697. 
Benasius, A. G. (2017). Stakeholders'perceptions on cash transfer program as strategy for poverty reduction in Tanzania (Doctoral dissertation, Mzumbe University).

Blattman, C., Fiala, N., \& Martinez, S. (2014). Generating skilled self-employment in developing countries: Experimental evidence from Uganda. The Quarterly Journal of Economics, 129(2), 697-752.

Bobonis, G. J., González-Brenes, M., \& Castro, R. (2013). Public transfers and domestic violence: The roles of private information and spousal control. American Economic Journal: Economic Policy, 5(1), 179-205.

Bradshaw, T. K. (2007). Theories of poverty and anti-poverty programs in community development. Community Development, 38(1), 7-25.

Brown, C., Ravallion, M., \& Van de Walle, D. (2016). A poor means test? Econometric targeting in Africa. The World Bank.

Burnell, J. D., \& Galster, G. (1992). Quality-of-life measurements and urban size: an empirical note. Urban Studies, 29(5), 727-735.

Cecchini, S., \& Martínez, R. (2012). Inclusive social protection in Latin America: a comprehensive, rights-based approach. Libro de la CEPAL, 111.

Cesarini, D., Lindqvist, E., Notowidigdo, M. J., \& Östling, R. (2017). The effect of wealth on individual and household labor supply: evidence from Swedish lotteries. American Economic Review, 107(12), 3917-46.

Cheng, C. (2019). Bantuan sara hidup (BSH) Design considerations for cash transfer programming https://www.isis.org.my/wp-content/uploads/2019/08/Bantuan-SaraHidup-Design-Considerations-fina.pdf

Chinnasamy, S., \& Azmi, N. M. (2018). Malaysian 14th General Election: Young Voters \& Rising Political Participation. International Research Journal of Social Sciences. 125138. 10.32861/jssr.spi4.125.138.

Daidone, S., Davis, B., Handa, S., \& Winters, P. (2019). The Household and Individual-Level Productive Impacts of Cash Transfer Programs in Sub-Saharan Africa. American Journal of Agricultural Economics, 101(5), 1401-1431.

De Souza, R. A., Nery, J. S., Rasella, D., Guimarães Pereira, R. A., Barreto, M. L., Rodrigues, L., \& Pereira, S. M. (2018). Family health and conditional cash transfer in Brazil and its effect on tuberculosis mortality. The International Journal of Tuberculosis and Lung Disease, 22(11), 1300-1306.

DOSM. (2019). Household Income \& Basic Amenities Survey Report 2019. Putrajaya : Department of Statistics Malaysia. Available from: http://www.dosm.gov.my

Ellis, F. (2008). 'We are all poor here': economic difference, social divisiveness, and targeting cash transfers in Sub-Saharan Africa. Social protection for the Poorest in Africa: Learning from Experience.

Evans, D. K., \& Popova, A. (2017). Cash transfers and temptation goods. Economic Development and Cultural Change, 65(2), 189-221.

FAO. (2015). FAO Technical Guide 2 Integrating gender into the design of cash transfer and public works programmes. http://www.fao.org/3/CA2038EN/ca2038en.pdf

Filmer, D., Friedman, J., Kandpal, E., \& Onishi, J. (2018). General equilibrium effects of targeted cash transfers: Nutrition impacts on non-beneficiary children. The World Bank.

Floate, H. J., Marks, G. C., Durham, J. (2019) Cash transfer programmes in lower-income and middle-income countries: understanding pathways to nutritional change-a realist review protocol BMJ Open 2019;9: e028314. doi: 10.1136/bmjopen-2018-028314 
Grosh, M. E., Del Ninno, C., Tesliuc, E., \& Ouerghi, A. (2008). For protection and promotion: The design and implementation of effective safety nets. The World Bank.

Handa, S., Natali, L., Seidenfeld, D., Tembo, G., \& Davis, B. (2018). Can unconditional cash transfers raise long-term living standards? Evidence from Zambia. Journal of Development Economics. 133. 10.1016/j.jdeveco.2018.01.008.

Haushofer, J., \& Shapiro, J. (2016). The short-term impact of unconditional cash transfers to the poor: experimental evidence from Kenya. The Quarterly Journal of Economics, 131(4), 1973-2042.

Hidrobo, M., Peterman, A., \& Heise, L. (2016). The effect of cash, vouchers, and food transfers on intimate partner violence: evidence from a randomised experiment in Northern Ecuador. American Economic Journal: Applied Economics, 8(3), 284-303.

Hossain, N., Brook, S., Garbarino, S., Notosusanto, S., Noor, I. R., \& Seda, F. (2012). Qualitative Assessment: The Social Impacts of Cash Transfer Programmes in Indonesia. Tim Nasional Percepatan Penanggulangan Kemiskinan (TNP2K).

Kamaruddin, R., Othman, A. A., \& Denan, Z. (2013). Government Sincere Initiatives or Political Motives of 1Malaysia Peoples' Aid: Using Structural Equation Modeling. Procedia-Social and Behavioral Sciences, 105, 715-722.

Lagarde, M., Haines, A., \& Palmer, N. (2009). The impact of conditional cash transfers on health outcomes and use of health services in low and middle income countries. Cochrane database of systematic reviews, (4).

Lawlor, K., Handa, S., Seidenfeld, D., \& Zambia Cash Transfer Evaluation Team. (2019). Cash transfers enable households to cope with agricultural production and price shocks: evidence from Zambia. The Journal of Development Studies, 55(2), 209-226. https://doi.org/10.1080/00220388.2017.1393519

Lloyd-Sherlock, P. (Ed.). (2004). Living longer: Ageing, development and social protection. Zed Books

Maluccio, J. A., \& Flores, R. (2004). Impact evaluation of a conditional cash transfer program: The Nicaraguan. Red de Protección Social", Fund Discussion Paper, 184.

Marimuthu, M., Arokiasamy, L., \& Ismail, M. (2009). Human capital development and its impact on firm performance: Evidence from developmental economics.

Marx, K. (1932). Economic and political manuscripts. Karl Marx: Selected Writings, 75-112.

Mills, M. (2019). Social Protection, Cash Transfers and Long-Term Poverty Reduction: Transfer Project Workshop Brief 2019 (No. inores1044).

New Straits Times. (2018). 'PM: Government will phase out BR1M'. New Straits Times. https://www.nst.com.my/news/nation/2018/08/404927/pm-government-willphase-out-br1m.

New Straits Times. (2019). 'BSH will raise govt debt, say experts'. New Straits Times https://www.nst.com.my/news/nation/2019/10/529221/bsh-will-raise-govt-debtsay-experts.

Nun, E., and Trucco, D. (2008). Report on the systematisation of qualitative evaluations of the Puente program and the Chile Solidario protection system. https://www.cl.undp.org/content/chile/es/home/library/poverty/documentos_de_t rabajo/informe-de-sistematizacion-de-evaluaciones-cualitativas-del-prog.html

OECD (Organisation for Economic Co-operation and Development). (2019). OECD Economic Surveys Malaysia. http://www.oecd.org/economy/surveys/Malaysia-2019-OECDeconomic-survey-overview.pdf

Selvester, K., Fidalgo, L., \& Taimo, N. (2012). Transforming Cash Transfers. 
Skovdal, M., Mushati, P., Robertson, L., Munyati, S., Sherr, L., Nyamukapa, C., \& Gregson, S. (2013). Social acceptability and perceived impact of a community-led cash transfer programme in Zimbabwe. BMC Public Health, 13(1), 1-13.

Slater, R., \& Farrington, J. (2010). Appropriate, Achievable, Acceptable: A Practical Tool for Good Targeting '. London: ODI.

Slater, R. (2011). Cash transfers, social protection and poverty reduction. International Journal of Social Welfare, 20(3), 250-259.

The Edge. (2016). Cover Story: Give BR1M to the right groups. The Edge. https://www.theedgemarkets.com/article/cover-story-give-br1m-right-groups

The Star. (2018). Reforms should benefit everyone, says Wan Azizah https://www.thestar.com.my/news/nation/2018/12/08/reforms-should-benefiteveryone-says-wan-azizah

The Sun. (2019) Even Datuks received BR1M aid under BN. The Sun. https://www.thesundaily.my/local/even-datuks-received-br1m-aid-under-bnEE732006

UNDP. (2016). Support In Developing National B40 Action Plan Using Innovative Bottom Up Approaches. Retrieved January 25, 2020 from https://www.my.undp.org/content/malaysia/en/home/operations/projects/poverty _reduction/ support-in-developing-national-b40-action-plan-using-innovative-.html

UNICEF. (2019). Cash Transfers. www.unicef.org

Vincent, K., \& Cull, T. (2009). Impacts of social cash transfers: case study evidence from across southern Africa. Instituto de Estudos Sociais e Económicos.

World Bank. (2018). Malaysia economic monitor. http://documents1.worldbank.org/curated/pt/136291544714446757/pdf/132903WP-P168289-Malaysia-Economic-Monitor-2018-12-Report-FA-Web.pdf

World Bank. (2019). Yes, global inequality has fallen. No, we shouldn't be complacent. https://www.worldbank.org/en/news/feature/2019/10/23/yes-global-inequalityhas-fallen-no-we-shouldnt-be-complacent

World Bank. (2020). The World Bank In Malaysia. Retrieved January 21, 2020 from https://www.worldbank.org/en/country/malaysia/overview

Yildirim, J., Ozdemir, S., \& Sezgin, F. (2014). A qualitative evaluation of a conditional cash transfer program in Turkey: The beneficiaries' and key informants' perspectives. Journal of Social Service Research, 40(1), 62-79.

Zimmerman, J., and Parker, S. (2012). From protection to inclusion: shifting to cashless payments. http://www.cgap.org/blog/protection-inclusion-shifting-cashlesspayments. 